\title{
Economic and social aspects of merger of territorial self-government units - Polish experience
}

doi:10.2478/mape-2019-0056

Date of submission to the Editor: $06 / 2018$

Date of acceptance by the Editor: 07/2018

MAPE 2019, volume 2, issue 1, pp. 559-569

Leszek Kaźmierczak-Piwko*

ORCID ID: 0000-0003-4460-7018

Piotr Dubicki

ORCID ID: 0000-0002-7812-8966

Adrianna Dybikowska

ORCID ID: 0000-0002-0078-9799

University of Zielona Góra, Poland

\section{INTRODUCTION}

Territorial self-government, defined by the European Charter of Local SelfGovernment as "the right and real ability of local communities to regulate and manage, as part of the law, on their own responsibility and for their people, an important part of public affairs" is a basic public authority that has legal personality and owns property rights and ownership rights that are municipal property (European Local Government Charter). In recent years in Poland, the concept of combining local government units aimed at seeking savings has become increasingly important in public, scientific and political discourse in the functioning of local government units and in meeting the needs of local communities more efficiently. The unique Polish case of combining two self-government units presented in the article with the example of combining the city and the commune of Zielona Góra shows, based on the conducted research, the socio-economic effects of such a process.

\section{FUNCTIONING OF TERRITORIAL SELF-GOVERNMENT UNITS IN THE REPUBLIC OF POLAND}

Creating cities in an economic context was the result of the social division of labour. Its beginnings date back to the time of separation and specialization of nonagricultural activities, which allowed for the expansion of the production capacity of a particular society for the production of goods allowing satisfying higher and higher needs (Czornik, 2013). The authors of the OECD report on the methods of identifying cities and urban areas stated that the criterion for delimiting cities should not be their administrative boundaries, but economic functions, also allowing determining the potential of a particular urban centre (OECD, 2012). In Polish law, the city is defined as: "a settlement unit created as a result of the expansion of the town beyond the area of previously existing buildings, in particular: a city colony, a village colony" (Journal of Laws 2003 No. 166, item 1612). The Act of 29 August 2003 on the official names

\footnotetext{
*I.kazmierczak@wez.uz.zgora.pl
} 
of towns and physiographic objects also distinguishes the following terms: settlement unit, colony, town, uninhabited settlement, settlement, village and others.

Subjectivity and independence of the local government expressed in the Constitution of the Republic of Poland and formulated in self-government acts, has a systemic significance for determining its position in the state and in law. Nowadays, the existence of territorial self-government is an important feature of the system of local authorities in democratic countries. In the Polish legal system, local self-government regulations appeared only after the introduction of relevant premises in the Basic Law (Gołębiowska et al., 2016). The process of the Europeanisation of administrative law and public administration in Poland had an impact on legal provisions contained in local self-government laws and in the Constitution of the Republic of Poland of 1997. In the Constitution of the Republic of Poland, the entire chapter VII was devoted to local self-government units; entitled: local self-government (Journal of Laws 1997, No. 78 , item 483). The commune was recognized as the basic local government unit and its independence is protected. The current constitution regulated in general terms the financing principles and the basis for the system of local government units by introducing constitutive bodies and executive bodies (Sławicki, 2013).

The legal context determines the essence of the city at least to the same extent as the economic one. Territorial self-government was created in urban areas and in the reality of their functioning, it was assumed that the jointly determined interest of the urban community is the overriding principle of managing local resources. Among a big number of tasks that should be implemented by the commune territorial selfgovernment under the Local Government Act (Journal of Laws 2019 item 506), one is particularly important, namely initiating, organizing, coordinating and supporting activities for the social and economic development of the commune. This obligation was written as taking actions to meet the collective needs of the local community and to deal with public matters having local significance. Such an obligation also results from the nature of local self-government, which creates the entire population of the commune (Parysek, 2015).

\section{THEORETICAL ASPECTS OF INTEGRATING PROCESSES OF TERRITORIAL SELF-GOVERNMENT UNITS}

Residents who seek to meet common needs and secure interests at the local level are self-governing communities, which are the irreversible entities of local selfgovernments. Both persons permanently resident in a particular commune, county (poviat) or voivodship as well as those staying on its territory temporarily - all are obliged to comply with the law established by the legislature. Therefore, the forced nature of the community is an expression of the need to integrate the inhabitants and a sense of responsibility for the common good and the prevailing situation (MańkaSzulik 2015). An inseparable element and a typical phenomenon of the urban development process is the movement of residents and business entities. This dynamic nature of society and the accompanying processes of globalization, including the acceleration and polarization of urbanization, the search for new forms of governance, the growing social inequality or the increase of multiculturalism of the regions, mean that the local self-government must constantly adapt to the changes taking place (Dubicki \& Kułyk, 2018).

One of such changes is the process of suburbanisation, or depopulation of the centre 
and the development of its external zones, which creates new links between the city and suburban areas, thereby exerting in spatial systems of cities. If the process of decentralization of central urban regions occurred in an uncoordinated manner, local self-government units would face numerous difficulties, for example in the preparation of investment areas, which would be a barrier to the development of the whole area, which should be constantly supervised. Defining the role of a commune in its own functional area will allow eliminating negative consequences, which - although the process itself is a phenomenon typical of urban areas - are often clearly emphasized (indicative of, among others, the loss of natural values and landscape, the need to increase public expenditures on infrastructure and public institutions, increase costs of urban development, dispersion of housing construction or the problem of the lack of coverage of the city's administrative borders with the functional area) (Dubicki \& Kułyk, 2018).

To prevent negative consequences, especially those related to problems in the functional and spatial structure, local self-government units may try to integrate administrative structures, expanding the scope of spatial central centres by broadening their administrative boundaries. Suburban municipalities are often unable to cope with the growing demand for infrastructure and public and market services, and despite the increasing income they are unable to finance these needs (Szewczuk, 2016). A comprehensive, not a sectoral approach to the development of a functional area, is now the basis for local development programming (Szewczuk, Potkański, 2016), and the integration process itself - especially if it is conducted with consent and consultation with residents - ensures greater integrity of functional areas, thus contributing to the development of the economic sphere (territorial marketing, creation of the so-called "urban brand" and more effective attraction of external investors, tourists and consumers), social (better access to health centres, education or culture, sense of belonging to the local community) and environmental (creation investment areas while maintaining green areas). The integration process requires the creation of new local government units, which contributes to reducing costs incurred by urban residents, ensures better integration of urban space (Dubicki, Kułyk, 2018) and allows the potential of communes, poviats and provinces to be stimulated, thus stimulating the whole region.

Entering into cooperation with neighbouring local governments or other public institutions also enables specialization in obtaining external funds and obtaining larger short-term revenues, which translates into higher co-financing of public tasks (Szewczuk, 2016). Above all, however, integration should be an expression of the desire to optimize the management of urban services and increase the efficiency of their delivery, without increasing fees at the same time and without increasing their own expenses for this purpose (Szewczuk, Potkański, 2016).

\section{ECONOMIC AND SOCIAL ASPECTS OF COMBINING LOCAL SELF- GOVERNMENT UNITS - POLISH EXAMPLE OF MERGER OF ZIELONA GÓRA CITY AND COMMUNE}

The course of the process and its costs.

The merger of two local government units, i.e. the city and commune of Zielona Góra, based on the Regulation of the Council of Ministers of 29 July 2014 on merging communes, establishing the boundaries of some municipalities and cities, granting 
some towns the status of a city and changing the seat of the commune authorities, (Journal of laws 2014, item 1023) was a unique process in the scale of Poland as a whole. The new, combined structure began its operation on January 1, 2015. Figure 1 shows the combined areas of the city of Zielona Góra and the areas of the former commune of Zielona Góra, which included the rural administrative units (sołectwa) indicated in the name ${ }^{\dagger}$.

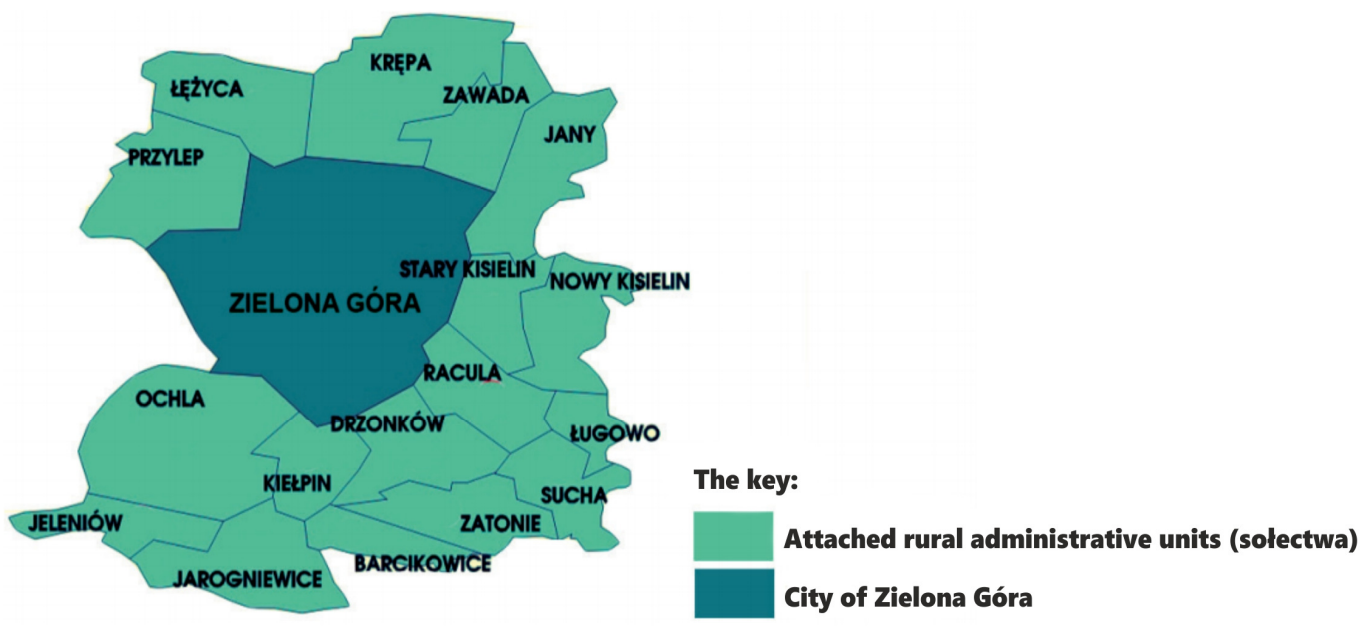

Fig. 1 Connected areas of the city and commune of Zielona Góra Source: (Dubicki \& Kułyk, 2018).

The decision of the Council of Ministers of the Republic of Poland was preceded by a long-lasting, democratic process in the form of a referendum among the residents of the Zielona Góra commune and consultations with the city's residents. On 18 May 2014, in a referendum carried out in the commune of Zielona Góra, 8336 people took part, i.e. $55.18 \%$ of those entitled to vote, out of whom $52.73 \%$ voted for the merger (Annex to Resolution No. LXIX.607.2014 Zielona Góra City Council, 2014 ).

However, on 17-30 June 2014, a social consultation process was carried out. In the consultations of those entitled to vote, 92462 residents of Zielona Góra participated, there were 32441 people who accounted for $35.09 \%$. $89.12 \%$ of people voted for the merger (Annex to Resolution No. LXIX.607.2014 Council of the City of Zielona Góra, 2014).

A very important aspect of the merger were the costs resulting from its implementation. And so, the estimated fixed costs of the merger is about 5.705 thousand PLN and were related to the unification of urban transport costs, reduction of educational subsidy, addition to family allowance for bringing up a child in a large family, equalization of property tax rates and local fees by taxpayers with lower charges, reduction of agricultural tax (Annex to Resolution No. LXIX.607.2014 Zielona Góra City Council, 2014).

On the other hand, one-off costs amount to 5.880 thousand PLN and result, among, others with:

- preparation of documentation for changing the real estate designation in land and mortgage registers and land and owner records,

\footnotetext{
$\dagger$ in the literature of the subject, "sołectwa" are commonly defined as auxiliary units of Polish communes, which have no legal personality and are created by resolutions of the municipal council
} 
- supply of geodetic and cartographic resources to the same software,

- adaptation of rooms,

- training of employees to conduct a geodetic and cartographic resource in new software,

- purchase of specialist equipment,

- elaboration of municipal records, a monument protection program for included monuments,

- changes in business register entries and exchange of stamps, signboards, plates, etc. (Annex to Resolution No. LXIX.607.2014 Zielona Góra City Council, 2014).

The above-mentioned costs became an integral part of the merger process, the aim of which was to contribute to "better allocation of functional areas in the expanded space" and consequently "improvement of the quality of life of the inhabitants of the structure" (Diagnosis of economic and social effects of the connection of Zielona Góra City and Commune, 2018).

\section{Diagnosis of the effects of the integration process of the city and commune}

The diagnosis of the economic and social effects of the connection of the City and Commune of Zielona Góra was prepared in 2018 by a group of scientists commissioned by the city of Zielona Góra and it was intended as an "attempt to provide information about the material and social resources of the new structure and to demonstrate the socio-economic effects of this process. It also includes determining the expectations of residents, people managing the institutions of this sphere and business entities as well as evaluating these activities from different perspectives. The main purpose of the diagnosis presented in this study was to create a picture of the condition and specificity of the connection of the City and the Commune of Zielona Góra" (Zielona Góra, 2018).

As we read in the research report, the evaluation of the integration process of local governments was "comprehensive" and included "analysis of the effects in the areas of: economy, investment, income, social aspects, demography, land use, culture" (Diagnosis of economic and social effects of the combination of the City and the Commune Zielona Góra, 2018).

\section{Research methodology}

During the implementation of the research process aimed at presenting, among others "information about the material and social resources of the new structure" (Diagnosis of the economic and social effects of the connection of the City and Commune of Zielona Góra, 2018) various methods and research techniques were used, among others desk research, surveys using the PAPI and CAWI questionnaire, statistical methods for the evaluation of highlighted phenomena. The aforementioned surveys used a random-layered sample selection and the opinion of 384 residents of villages "forming" the municipality included in the city of Zielona Góra was their part as well (Diagnosis of economic and social effects of the connection of the City and Commune of Zielona Góra, 2018).

For the finite population, the formula for the minimum sample size of the following form was accepted as: 
where:

$$
N_{\text {min }}=\frac{P(1-P)}{\frac{e^{2}}{Z^{2}}+\frac{P(1-P)^{\prime}}{N}}
$$

$P$ - estimated fraction size ( $50 \%$ was assumed as standard),

$z-$ the value resulting from the assumed level of significance ( $\alpha)$, calculated using the normal cumulative distribution - (assumed - 0,05),

$\mathrm{N}$ - the size of the general population (in the case of a finite population),

$e$ - the maximum estimation error (5\% was assumed) (Diagnosis of economic and social effects of the connection of the City and Commune of Zielona Góra, 2018).

\section{Findings}

During the surveys conducted, the respondents' task was to respond to the statements provided in the questionnaire (do they agree with them?) by indicating the appropriate assessment in the $5^{\text {th }}$ Likert scale (I strongly agree, rather agree, hard to say, rather disagree, strongly disagree) (Diagnosis of economic and social effects of the connection of the City and Commune of Zielona Góra, 2018).

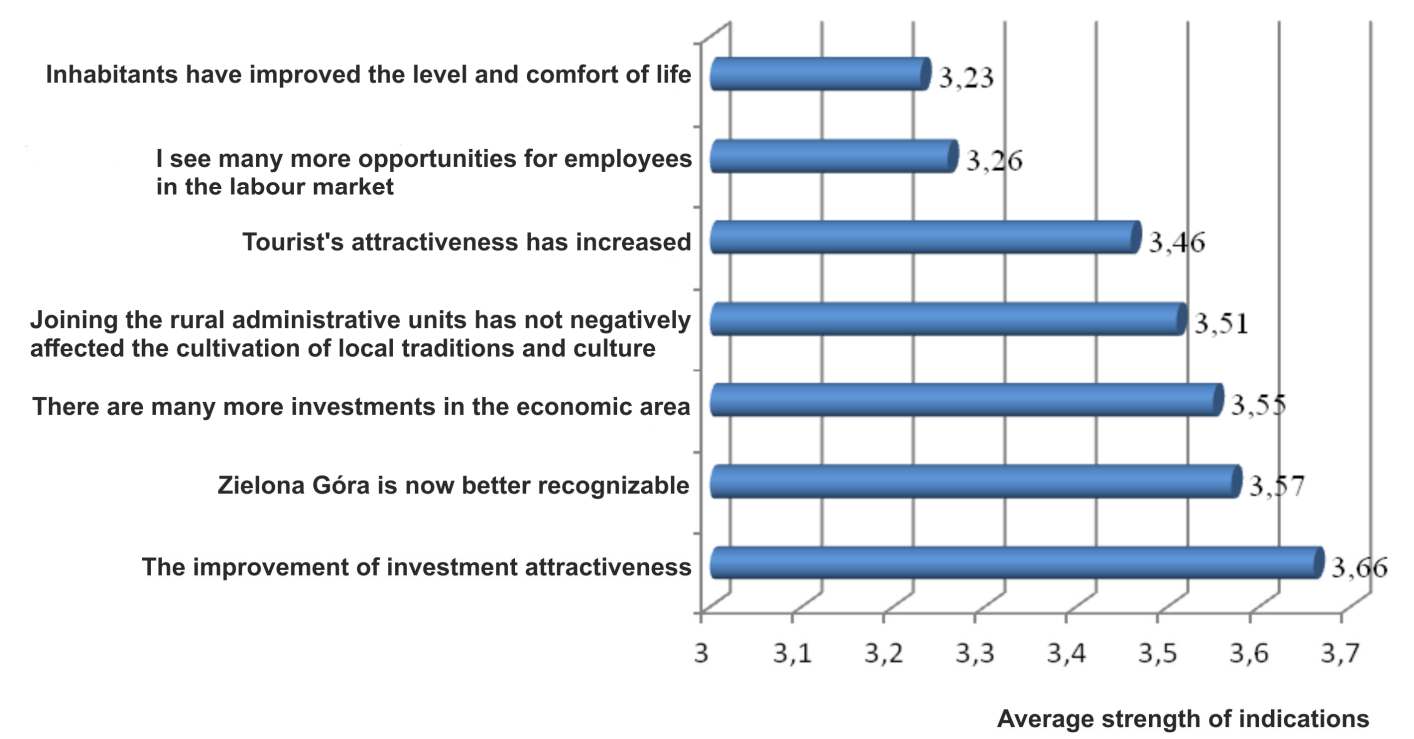

Fig. 2 Average strength of indications for the evaluation of statements from the connection of the Commune and the City of Zielona Góra

Source: Diagnosis of the economic and social effects of the connection of the City and the Commune, Zielona Góra 2018.

As shown in Figure 2, the residents as the most important effect of the merger of the city and the commune of Zielona Góra indicated the "economic-image" aspects related primarily to the improvement of investment attractiveness, recognition of the "enlarged" city of Zielona Góra and increased investment volume in the economic area.

During the research, respondents were also asked to indicate, in their opinion, the most important positive effects of the process of combining two local government units for local communities - they were asked to indicate the 3 most important of the 7 surveyed questionnaires - the research results are presented in Table 1. 
Table 1

Respondents' opinion on positive socio-economic aspects resulting from the merger of the City and the Commune

\begin{tabular}{|c|c|c|}
\hline Specification & $\begin{array}{c}\text { Number } \\
\text { of indications }\end{array}$ & $\begin{array}{c}\text { Percentage } \\
\text { of indications [\%] }\end{array}$ \\
\hline Lower taxes and local fees & 73 & 5.87 \\
\hline Price reduction of public transport tickets & 337 & 27.11 \\
\hline Belonging to a larger agglomeration & 188 & 15.12 \\
\hline Infrastructure investments & 145 & 11.67 \\
\hline $\begin{array}{l}\text { Ability to use the facilities for Zielona Góra } \\
\text { residents, such as receiving the card of the } \\
\text { ZGrana Rodzina } \\
\text { and ZGrani Zieloogórzanie } 50+\text { and others. }\end{array}$ & 276 & 22.20 \\
\hline More land for investment & 86 & 6.92 \\
\hline Price increase for agricultural/construction plots & 68 & 5.47 \\
\hline Other (what?) & 70 & 5.63 \\
\hline Altogether & 1243 & 100.00 \\
\hline
\end{tabular}

Source: Diagnosis of economic and social effects of the connection of the City and the Commune, Zielona Góra 2018.

As Table 1 shows, by far the largest number of people, over $27 \%$, indicated the reduction in the price of public transport tickets as the biggest positive result of the combination of the city and the commune. In the next place respondents placed the possibility of using the facilities in the form of urban programs for residents such as the ZGRana Rodzina card, Zgrani Seniorzy 50+ and other enabling discounts on many services offered in the city.

Table 2

Respondents' opinion on negative aspects of the merger of the Commune and the City

\begin{tabular}{|c|c|c|}
\hline Specification & $\begin{array}{c}\text { Number } \\
\text { of indications }\end{array}$ & $\begin{array}{c}\text { Percentage } \\
\text { of indications [\%] }\end{array}$ \\
\hline Loss of rural character of the village/town & 188 & 21.34 \\
\hline $\begin{array}{c}\text { Necessity to change documents (e.g. identity } \\
\text { card, etc.) }\end{array}$ & 177 & 20.09 \\
\hline Greater distance to offices & 69 & 7.83 \\
\hline $\begin{array}{c}\text { Price change for agricultural/construction } \\
\text { plots }\end{array}$ & 149 & 16.91 \\
\hline $\begin{array}{c}\text { Formal and administrative burdens (e.g. } \\
\text { changes in addresses, documents, etc.) }\end{array}$ & 185 & 21.00 \\
\hline $\begin{array}{c}\text { Increase in the costs of running a business } \\
\text { (e.g., rental rates, etc.) }\end{array}$ & 89 & 10.10 \\
\hline Other (what?) & 24 & 2.72 \\
\hline Altogether & 881 & 100.00 \\
\hline
\end{tabular}

Source: Diagnosis of economic and social effects of the connection of the City and the Commune, Zielona Góra 2018.

As shown in Table 2, in the course of research, the most important negative effects for themselves the residents mentioned: "Loss of the rural character of the village/town" $-21.34 \%$ of indications, "necessity to change in documents" $-20.09 \%$ of responses, "formal and organizational difficulties" related to, among others with address changes - $21 \%$ of responses and "change in prices of agricultural/construction plots" - $16.91 \%$ of responses.

The integration process of the city and the commune also had its positive economic aspects connected with the income of the enlarged city of Zielona Góra. As Figure 3 shows, their rapid growth followed the merger of the city and the commune, which 
undoubtedly should be considered as one of the greatest economic benefits for the City.

\section{Own income}

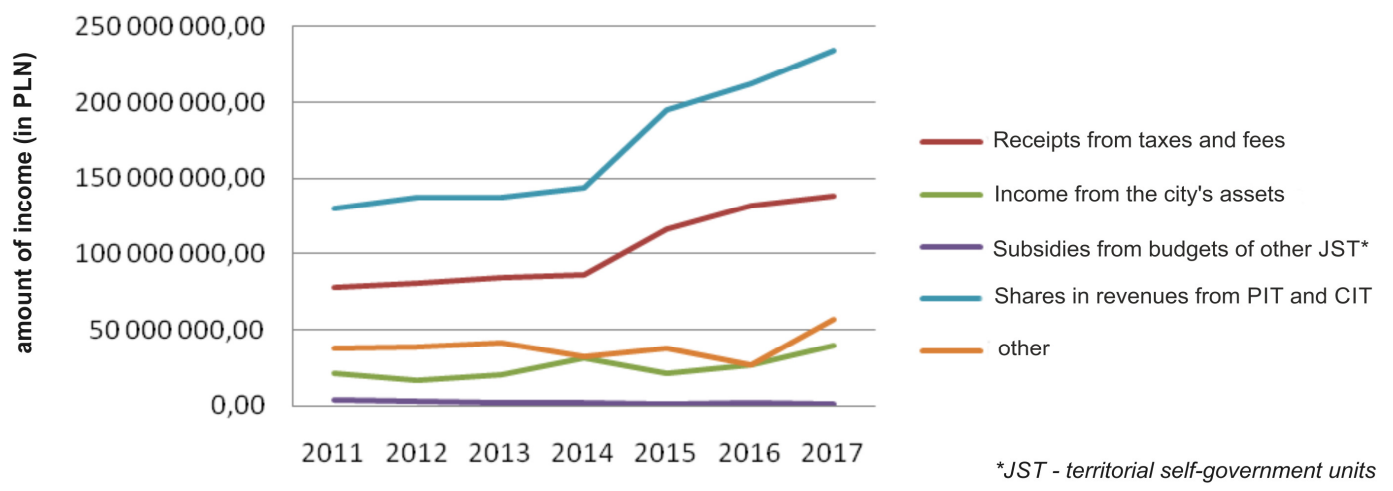

Fig. 3 Changes in own revenues of the City of Zielona Góra in the years 2011-2017 Source: Diagnosis of the economic and social effects of the connection of the City and the Commune, Zielona Góra 2018.

It is worth emphasizing that on the basis of the so-called The Zielona Góra contract (Declaration No. LXVI.1.2014 of the Zielona Góra City Council and annex, 2014) the former Zielona Góra commune will be allocated to within 5 years after the merger for the development with a minimum of 100 million PLN (Integration Fund), including 70 million PLN from so-called "Ministerial bonus", and 30 million PLN from other sources obtained by the city of Zielona Góra.

One of the elements of the diagnosis was to determine the impact of the integration process on the quality of life of the inhabitants of the newly-created urban structure. More than half of the respondents said that after the combination of the city and the commune, their living conditions improved, $15 \%$ of whom decided that they improved significantly. A detailed assessment of this aspect is shown in Figure 4.

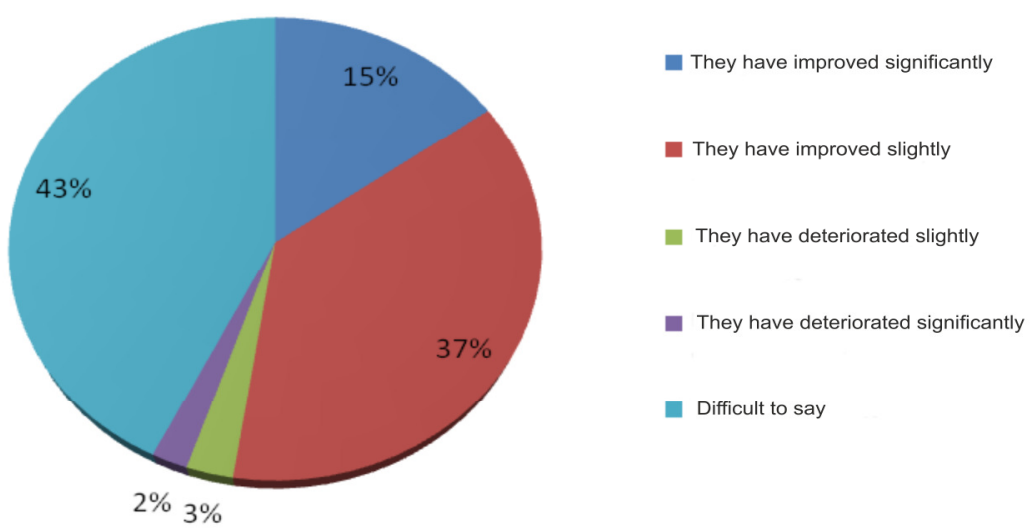

Fig. 4 Living conditions after connecting the city and the commune

Source: Diagnosis of the economic and social effects of the connection of the City and the Commune, Zielona Góra 2018.

A very important aspect of quality of life, but the foundation of economic processes is road infrastructure. As Figure 5 shows, more than $62 \%$ of respondents positively assessed changes in the road infrastructure of the integrated area indicating that it is "better" or "much better". 


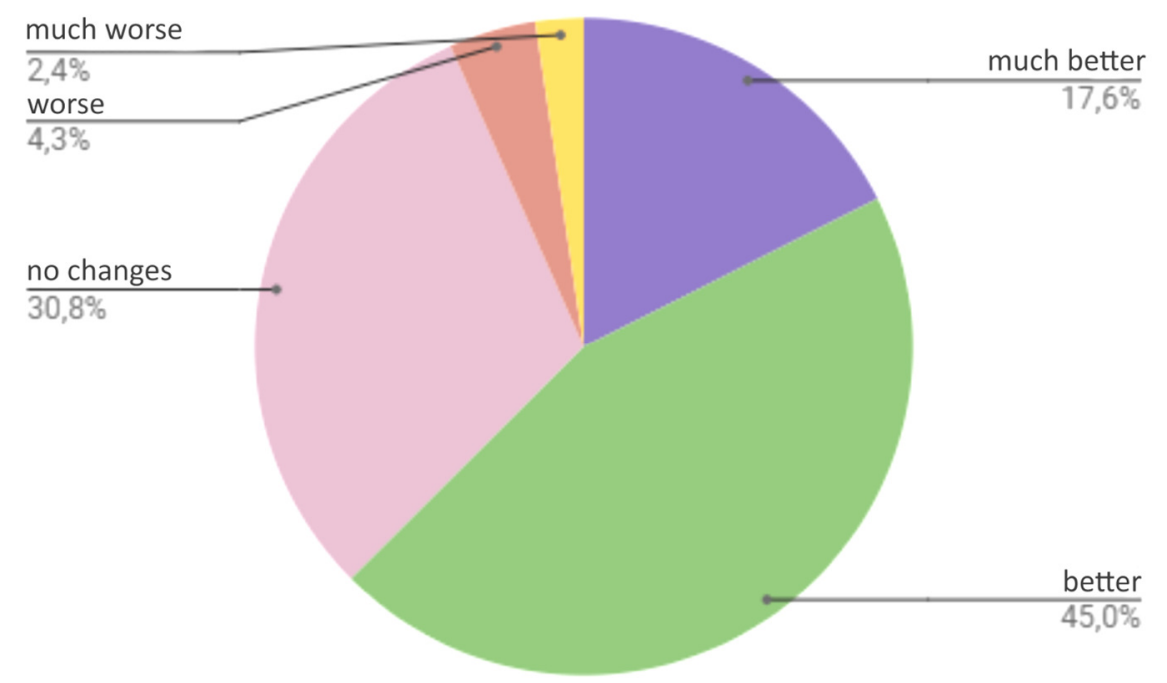

Fig. 5 Assessment of changes in the New City road infrastructure

Source: Diagnosis of the economic and social effects of the connection of the City and the Commune, Zielona Góra 2018.

\section{CONCLUSIONS}

The article has dealt with the issue of combining local self-government units with the Polish example of connecting the city and commune of Zielona Góra on January 1 , 2015. As shown in the research presented in this article, carried out on behalf of the city of Zielona Góra 3 years after the merger, residents of the connected areas positively assessed this process, indicating the main benefits resulting from it. The results of the research clearly proved that these profits concentrated in the economic and social area in the aspects of: improvement of living conditions, which was indicated by more than $50 \%$ of respondents, improved investment attractiveness of the increased Zielona Góra, recognition of the "enlarged" city, increased investment volume in the economic area and positive changes in road infrastructure. A very important aspect assessed positively as a result of the merger process was the improvement of the conditions for the functioning of public transport in the former commune in terms of transport costs, manifested in the reduction of ticket prices. The analysis of the city's income before and during the merger also pointed to their rapid growth after the integration of both local government units.

At the same time, among the negative sides, the inhabitants mentioned the loss of rural character of the former commune's area and formal problems resulting from the need for changes in personal ID cards and other documents related to the new address of residence, company headquarters, etc.

To sum up, it is worth noting that the integration process has not yet been completed, but after three years of its functioning in the light of the information and research results presented in this article, it can be assessed positively. The fact secured as a result of the so-called Zielona Góra contract has provided a five-year inflow of funds to the area of the former commune, amounting to 100 million PLN, which can be positively used for the structural changes of these areas and even greater improvement of the quality of life of residents in the coming years, is regarded as extremely significant. 


\section{REFEENCES}

Application to the Minister of Administration and Digitization of the Republic of Poland for a regulation regarding the merger of Zielona Góra City and Zielona Góra Commune into one local government unit, Annex to Resolution No. LXIX.607.2014 of the Zielona Góra City Council of 8 July 2014. Zielona Góra City Council 2014, [online] Available at: http://bip.zielonagora.pl/system/obj/37950_0607-LXIX-2014-z01.pdf

Czornik M., (2013), Miasto i jego produkty [in:] Studia Ekonomiczne, Uniwersytet Ekonomiczny w Katowicach, no. 147 Turystyka miejska. Prawidłowości i determinanty rozwoju, pp. $36-52$

Declaration No. LXVI.1.2014 of the Zielona Góra City Council of May 6, 2014 regarding the merger of Zielona Góra City and Commune as well as the appendix "Zielona Góra Contract"

Diagnosis of economic and social effects of the connection of Zielona Góra City and Commune (research report) (2018), Zielona Góra,, pp. 1-55 - Document provided by the City of Zielona Góra

Dubicki P., Kułyk P., (2018), Proces integracji miasta z gminą wiejską. Przykład Zielonej Góry [in:] Studia Miejskie vol. 32, pp. 113-124 [online] Available at: http://www.studiamiejskie.uni.opole.pl/wpcontent/uploads/2019/05/S_Miejskie_32_2018-Dubicki.pdf

Gołębiowska A., Zientarski P., Stępień E., (2016), Konstytucja Rzeczpospolitej Polskiej a samorząd terytorialny, [in:] Funkcjonowanie samorządu terytorialnego uwarunkowania prawne i społeczne, Warszawa, pp. 13-23.

Journal of Laws 1994, no. 124, item 607, European Charter of Local Self-Government. Art. 3 points 1 and 2 .

Journal of Laws 1997, No. 78 item 483 - The Constitution of the Republic of Poland of 2 April 1997

Journal of Laws 2003 No. 166 item 1612 - Act of 29 August 2003 about official names of towns and physiographic objects

Journal of Laws 2019 item 506 - Act of 8 March 1990 on local government

Mańka-Szulik M., (2015), Samorząd terytorialny jako czynnik rozwoju lokalnego i regionalnego [in:] Zeszyty Naukowe Politechniki Śląskiej, Organizacja i Zarządzanie z. 79, nr kol. 1930.

OECD (2012), Redefining „Urban”. A New Way to Measure Metropolitan Areas. Paris: OECD Publishing.

Parysek J., (2015), Rola lokalnego samorządu terytorialnego w rozwoju społecznogospodarczym i przestrzennym gmin [in:] Ruch prawniczy, ekonomiczny i socjologiczny no. 3, pp. 27-46.

Regulation of the Council of Ministers of 29 July 2014 on the merger of communes, establishing the boundaries of some municipalities and cities, granting some towns the status of a city and changing the seat of the commune authorities (Journal of Laws 2014, item 1023).

Sławicki P., (2013), Samorząd w uregulowaniach Konstytucji z 1997 r., [in:] M. Klimek, J. Czerw, B. Więckiewicz, Samorząd gminny w III Rzeczpospolitej. Doświadczenia i perspektywy, Lublin, p. 92

Szewczuk J., (2016), Przed jakimi wyzwaniami stoją samorządy i dlaczego muszą współpracować? [in:] Współpraca jednostek samorządu terytorialnego narzędziem wsparcia polskiej polityki rozwoju, Związek Miast Polskich, Poznań, pp. 13-26.

Szewczuk J., Potkański T., (2016), Integracja systemu zarządzania rozwojem obszarów funkcjonalnych - rekomendacje metodologiczne [in:] Współpraca jednostek samorządu terytorialnego narzędziem wsparcia polskiej polityki rozwoju, Związek Miast Polskich, Poznań, pp. 117-126. 
Abstract. The article deals with the issues of merging Local Government Units (LGU). Based on Polish experience related to the unique process of integration of the city and the commune of Zielona Góra in 2015, the authors present the most important economic and social aspects of combining local government units. The article also presents important elements of the process of creating a new functional area from two different neighbouring local government units. Moreover, the exemplified research results, carried out in 2018 among residents of the commune annexed to the city, concerning the economic and social effects of the integration process, made available by the City of Zielona Góra for the purposes of this article, were presented and discussed there. At the same time, a synthetic evaluation of this process was carried out in the light of the documents analysed in the article that form the basis of the merger process and presented results of empirical research.

Keywords: integration of territorial self-government units, connection of the city and the commune, effects of integration of the country's administrative units, integration processes, economics of integration 